\title{
If THE ApACHES ARE THE INSTRUMENT OF THE DEVIL:
}

\section{The Dual Diplomacy of Father Kino, Borderland Missionary}

\author{
By Serena Luzzi
}

\begin{abstract}
Padre Eusebio Kino (I645-I7II), known as the builder of missions, explorer of New Spain's northern reaches, protective pastor of Native American converts, and diplomat for peace on the borderlands, also instigated military attacks on Indigenous peoples who resisted Christianity and Spanish rule, drove his converts to take up arms against them, and celebrated brutal victories. He did these actions with a clean conscience by determining that his adversaries were instruments of the Devil and by appealing to legalities. This article explores Kino's exercise of this second, militant kind of diplomacy by making a close comparison of his own account of his years in the Pimería Alta with the accounts of his Spanish military counterparts.
\end{abstract}

Keywords: missions in the Pimería Alta; Eusebio Francesco Chini (Father Kino); Padre Eusebio Kino; borderlands history; Apaches; Spain's Indian policy

mong the missionaries active along the northern fron-
tier of New Spain, Eusebio Francesco Chini is undoubt-
edly the best known, at least since the American

Southern California Quarterly, Vol. 99, No. 4, pp. 425-442. ISSN 0038 -3929, eISSN 2162-8637. (C) 2017 by The Historical Society of Southern California. All rights reserved. Request permission to photocopy or reproduce article content at the University of California Press's Reprints and Permissions web page, http://www.ucpress.edu/journals.php?p=reprints. DOI: https:/ / doi.org/10.1525/scq.2017.99.4.425. 
in I9I9. ${ }^{\mathrm{I}}$ Bolton then devoted to Chini-also known as Kino or Father Kino - two important biographies that made the Jesuit a special, heroic figure: a tireless missionary, an acute explorer (who proved that California is a peninsula), a civilizing pioneer of the frontier, a staunch defender of the natives against the abuses of Spanish soldiers and colonists. In 1964, a statue of Kino was placed in the National Statuary Hall in Washington as representative of the state of Arizona. ${ }^{2}$ Then, in I97 I, the process of Father Kino's beatification began (the outcome is still awaited). In 20 I I, three hundred years after the missionary's death, numerous initiatives on each side of the Atlantic celebrated "the Father on Horseback," as Bolton called him, thus providing the image that has inspired a flourishing iconography. Bolton's studies had the merit of drawing attention to Kino's activity_although their hagiographic slant is evident — and of marking out new lines of inquiry. However, neglected to date have been aspects that make the figure of Kino more composite and complex than that described by the traditional and consolidated accounts. This article considers in particular the position taken by Kino against the native populations that rejected Christianization, such as Apaches, nomads, and warrior tribes. Overall, it is necessary to investigate Kino and (I) his legitimation of violence, and (2) the inclusion and exclusion dynamics that determined his missionary activity in a context characterized by endemic and growing violence. The comparison of Kino's account with military diaries of the same eventsneglected sources in the historiography of the Jesuit-is an essential element of this article, bringing to light the militant side of Kino's activity and providing new information about his role in the processes of pacification. As we shall see, it was the concept of a "just war" that represented for Kino the filter, both legal and theological, through

I. Eusebio Francisco Kino, Cronica de la Pimería Alta. Favores celestiales (Hermosillo: Gobierno del Estado de Sonora, 1985). The work was written between r699 and I7 Io and was dedicated to the King of Spain. Remaining in manuscript form, until it was rediscovered by Herbert Eugene Bolton, who describes its publication in Rim of Christendom: A Biography of Eusebio Francisco Kino, Pacific Coast Pioneer (Tucson: The University of Arizona Press, I984), viii. On Bolton's work see Bernd Hausberger, "El padre Eusebio Francisco Kino, S.J. (I645-I7II), la misión universal y la historiografía nacional," in Salvador Bernabéu Albert (ed), El gran Norte Mexicano: Indios, misioneros y pobladores entre el mito y la historia (Sevilla: CSIC, 2009), 230-32. And, in this issue, Alessandra Lorini, "The Pageant of Father Kino: From History to Public Memory and the Making of Usable Pasts," and the rich bibliography cited therein.

2. For the context, see Lorini, "The Pageant of Father Kino." 
which to handle-morally, diplomatically, and practically - the uprisings of Christianized natives and, above all, the response to the attacks of the warrior tribes of the Apaches, the enemy par excellence.

\section{Pacification Policy in the Pimería Alta}

The "pacification" of populations living in the peripheries of the Spanish overseas colonies was an objective pursued by the Crown for three centuries after the Conquista, the conquest of the New World. The term pacificación appeared for the first time in the Ordenanzas para Descubrimiento, nueva población y pacificación de las Indias) of I573 (Ordinances for Discoveries, New Settlements, and Pacifications). It did so on the instructions of Philip II, marking a significant change in the methods adopted hitherto for territorial expansion in the Americas. The relationship between Spaniards and Indigenous peoples and the armed resistance raised by many ethnic groups settled along the frontiers required new legal measures, new concepts, and "peaceful techniques of subjugation." 3 The purpose was to obtain recognition of Spanish sovereignty from the natives and thus take effective possession of territories which otherwise, in point of law, could not fall under the jurisdiction of the Catholic King. ${ }^{4}$ The diplomatic option and peace treaties were urged by both theologians and the military, who deemed the use of war and violence as morally reprehensible, economically costly, and ineffective. In this well-defined political-military and legal context, the missionaries mediated between the parties involved in armed conflicts. This oscillation between the options of war or peace was also a central aspect of the work of Eusebio Francesco Chini (as Father Kino was known in his native Italy): diplomatic action in peace processes but also in the promotion of war. These are aspects substantially ignored by the otherwise ample historiography devoted to the well-known Jesuit.

In 1687 , Father Kino reached the region of Sonora and Sinaloaindicated by the Spaniards as Pimería Alta, today's borderland between Mexico and Arizona. During his itinerant preaching, Kino would come across villages where no European, neither a colonial

3. Carlos Lázaro Ávila, "Conquista control y convicción: el papel de los parlamentos indígenas en México, El Chaco y Norteamérica," Revista de Indias 2 I 7 (I999): 645-73.

4. Abelardo Levaggi, Diplomacia Hispano-Indígena en las fronteras de América. Historia de los tratados entre la Monarquía española y las comunidades aborígenes (Madrid: Centro de Estudios Constitucionales, 2002), particularly pages $13 \mathrm{ff}$. 
soldier nor a missionary, had ever set foot, even though there were already fifty-five missions in the northern Spanish frontier by $\mathrm{I} 662$. By I7 I I, when Kino died, he had founded an additional twenty-seven permanent missions in the north of Pimería Alta, spread over a radius of 240 kilometers. The Jesuit missionary therefore came into contact with numerous tribes whose original names would be changed by the colonizers: they were the Pima of the south and those of the north, the Nevome, the Seri, the Pima; the people of the river (Akimel O'odham) and the Pápago; and the people of the desert (Tohono O'odham), the Opas, Cora, Cocomaricopas, Guaycuros, Guaymas, Yaquis, and Mayo. They lived in scattered and independent settlements: some tribes were sedentary, others semi-nomadic, others nomadic; some were markedly bellicose. The most prosperous groups were settled along the rivers; much less prosperous or close to subsistence level were those settled near the "Great Desert" of Sonora. ${ }^{5}$

Revolts of the neophytes, armed resistance by non-evangelized Indigenous peoples, and Spanish military campaigns were realities that imposed themselves on Kino's daily life, forcing him to deal with the onerous issue of the legitimacy of the war both against the rebellion by the newly Christianized subjects and against the resistant and combative tribes. On reading the diary-memoir kept by Kino and given the title Favores celestiales (Celestial Favors) one gains a sense of the substantial state of war in which he worked. But Kino's writings and correspondence are the expression of a specific point of view. Therefore, because of their partial nature, they do not allow one to fully grasp the difficult and often bloody circumstances of the "pacification" in which the missionary moved and the strongly coercive elements that it entailed. Nor does it allow measurement of the spaces of mediation actually covered by the priests or those granted to them by the Spanish authorities and the soldiers active in the control of the territory and the repression of revolts. On the other hand,

5. The expression Pimas Altos refers to the three ethnic groups constituting the O'odham, whom the Spanish renamed Pima: Akimel O'odham (river people), Tohono O'odham (desert people), Hia C-ed O'odham (sand people). To be noted, however, is that each settlement was autonomous from the others: see David H. Dejong," None Excel Them in Virtue and Honesty: Ecclesiastical and Military Descriptions of the Gila River Pima,1694-1848," American Indian Quarterly 29:I-2 (2005): 24-25; Bernard L. Fontana, "Pima and Papago: Introduction," in Alfonso Ortiz (ed), Handbook of North American Indians, Io, (Washington DC: Smithsonian Institution, 1983), 125-36; and Bernard L. Fontana, "History of the Papago," (ibid., I37-39); Paul H. Ezell, "History of the Pima," (ibid., I49-55); Timothy Dunnigan, "Lower Pima," (ibid., 217-29); and Donald M. Bahr, "Pima and Papago Social Organization," (ibid., 178-92). 
Kino's cautious style invites the reader to consider the circumstances in which he was writing, the recipients and the purposes of his letters, and the fact that Favores celestiales was a text largely written years after the events narrated and therefore based on hindsight. In order to integrate and contextualize the actions of missionaries in their role as diplomats, it is therefore necessary to look at other sources, in particular military reports and war diaries. ${ }^{6}$ In what follows, frequent references will be made to these sources, and especially to the voluminous report compiled by General Juan Fernández de la Fuente, ${ }^{7}$ who was engaged along the border in military expeditions against rebels and hence with the peace agreements. Fuente furnishes ample data, allowing comparison with the reconstruction of those same circumstances mentioned by Kino and hence yielding a more adequate understanding of the pacification process, its actors, and the diplomatic and ideological positions taken by the missionaries and by Kino in particular.

\section{Friends, Enemies, Rebels}

Spaniards and missionaries classified the native peoples of the borderland into friends (indios amigos) and enemies (enemigos). But there was a third category, that of the rebels (rebeldes): tribes already approached by missionaries and Spanish troops, already bound to the faith by baptism and to the monarchy by obedience, but that then revolted. An episode indicative of the dynamics of inclusion and exclusion activated in the

6. On the value of the Spanish military reports for study of the native revolts of the late r6oos see: Luis González Rodriguez, "Las guerrillas de resistencia étnica en el noroeste (I69o). Un análisis de la documentación oficial,” in Felipe Castro Gutiérrez, Virginia Guedea, and José Luis Mirafuentes (eds), Organización y liderazgo en los movimientos populares novohispanos (México: Universidad Autónoma de México, I992), 37-45. More generally, for historiographical revision concerning studies on the northern provinces of colonial Mexico and the relationship between Spaniards and natives see: S. Bernabéu Albert (ed), El gran Norte Mexicano; in particular, on the missionary system see pages I65-2 I2, and Hausberger, El padre Eusebio Francisco Kino. Furthermore Ignacio Almada Bay, José Marcos Medina Bustos, and María del Valle Borrero Silva, "Hacia una nueva interpretación del régimen colonial en Sonora. Descubriendo a los indios y redimensionando a los misioneros, I68II82 I," Región y sociedad. Revista de El Colegio de Sonora, ig (2007) http:/ / www.scielo.org.mx / scielo. php?pid=SI 870-392520070004000 I 2 \& script=sci_arttext\&tlng=pt.

7. The report took two months to write, from June 17 to October 3, I695. It is an extraordinary source, like the campaign that produced it, with its long duration and number of soldiers involved. A transcript of large portions of the report (henceforth: Fuente, Autos de guerra) edited by Francisco Ignacio Gómez Robledo is in The Presidio and Militia on the Northern Frontier of New Spain: A Documentary History. vol. I: I 500-1700, eds. and trans. Thomas H. Naylor, Charles W. Polzer (Tucson: University of Arizona Press, 1986), 585-656 (translation and summaries in English) and 656-718 (original version in Spanish). 
province of Sonora and Sinaloa was the revolt that erupted on March 29, 1695: an outright act of war against the Spanish, and also warfare against the missions and missionaries of the Pimería Alta. It involved bonds of honor, inter-tribal relations, and an extensive network of Native alliances. On April 2, the most grievous event occurred: the rebels killed a colleague of Father Kino, the young Sicilian Jesuit Francesco Saverio Saeta (Francisco Javier Saeta, in Spanish), together with his four assistants, natives who had just been Christianized (Fig. I).

Who were responsible? The web of alliances arrayed against the Spanish was extensive and involved several nations: among them were the Apaches. A leading role in the revolt was played by a tribe recently converted by Father Kino, a group of the O'odham Nation, the Pimas Sobaipuri (the name is the Spanish one). Spanish soldiers proceeded with punitive campaigns. From the point of view of the Crown, and in accordance with codes and canons, it was a just war (justa guerra) against former allies who had rebelled against the constituted authority and were "apostate Christians," 8 having attacked churches and missionaries. Those responsible were punished with the death penalty: their severed heads were impaled on stakes in public, where they remained for weeks. But the "pacification" was not easy. The option of treaties and amnesties imposed itself as the most convenient way to halt the war, at least provisionally. ${ }^{9}$ The ultimatums were particularly harsh: if the rebel leaders did not "sue for peace," a war with no quarter would be declared, with children and adults put to the sword without regard to sex and age. ${ }^{\text {Io }}$ Such threats, however, seemed to be a manifestation of weakness rather than strength, given the extreme difficulty with which the Spanish troops were advancing

8. See Fuente, Autos de guerra, I, for example, pp. 520 and 527 ("Otro si en la campaña que salió por orden de su señoría a buscar los apóstatas alzados de la nación mansos de sus aliados y confederados del valle de Casas Grandes donde hice castigo y justa guerra, a los apóstatas cristianos de nación suma, janos y otras ... ”. "Also during the expedition ordered by his lordship to seek out the apostates of the Manso nation who had rebelled with their allies and confederates of the Casas Grandes area, where I punished and gave just battle to the apostate Christians of the Suma, Janos and other nations ... ") and p. 545 .

9. See at least A. Levaggi, "Diplomacia Hispano-Indígena," and Abelardo Levaggi, "Los tratados hispano-indígenas en las fronteras septentrional y meridional de América. Análisis comparativo," in Óscar Mazín Gómez (ed), México en el mundo hispánico (Zamora: El Colegio de Michoacán, 200o), 579-90.

ı. "... les haríamos la guerra a fuego y sangre, llevando a cuchillo chico y grande sin reservar sexo ni edad en que los topáramos por de canto." "If they did not do this ["to deliver over to us the leaders of the uprising"], a war of fire and blood would be waged again ... we would destroy their crops and both young and old would die from hunger and the power of our weapons." Fuente, Autos de guerra (August 3, I695), 599 (translation), 690 (original version), similarly 626, 665, and 693 . 


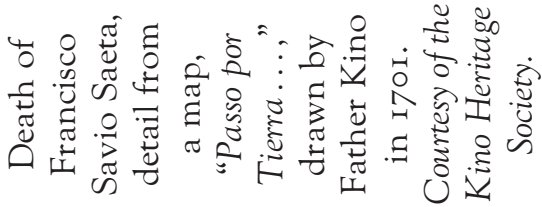

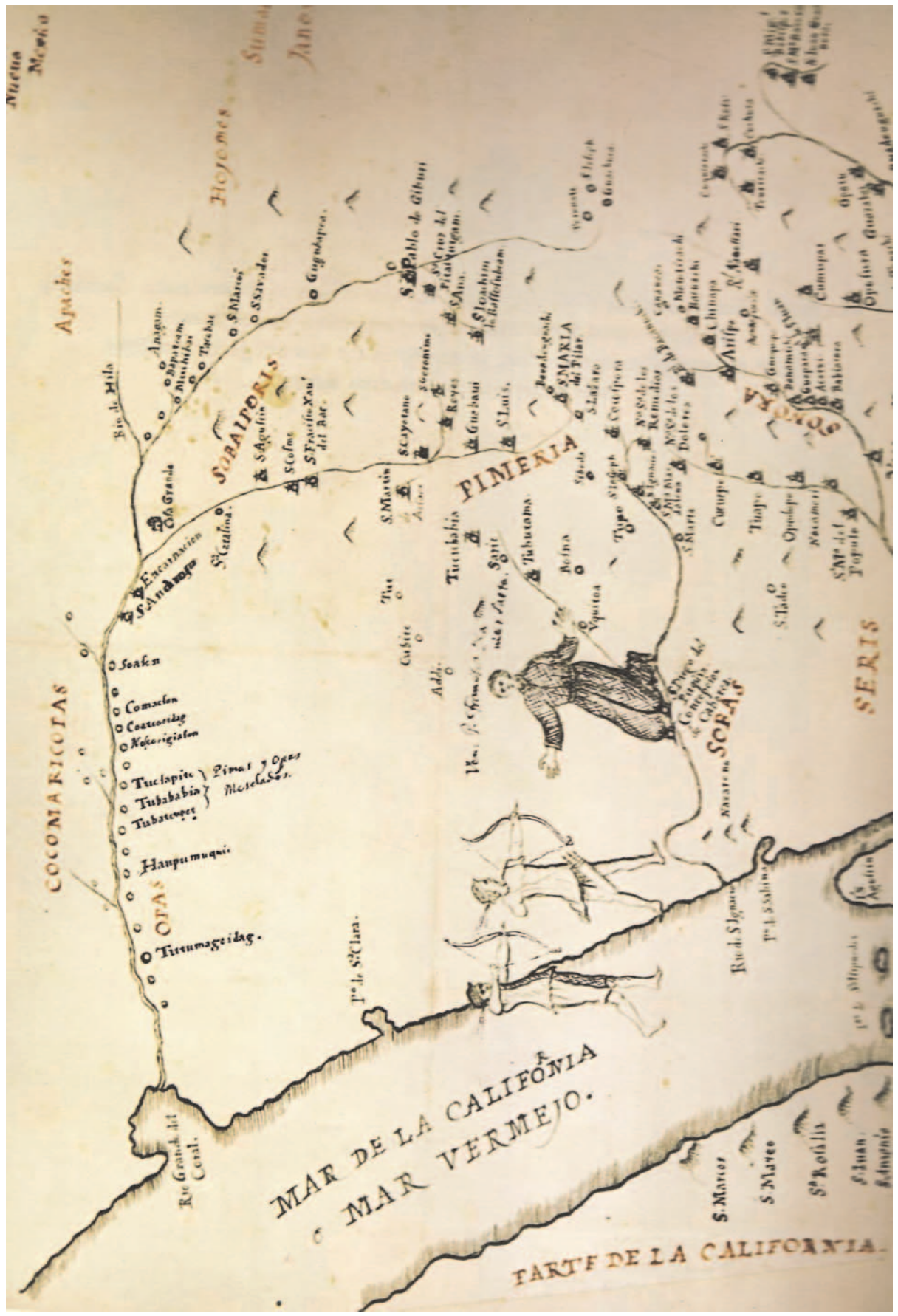


in their vain search for the rebels. But if the military reports refer to difficulties and frustrations, they also show the severity with which the punitive expeditions were conducted: for instance, crops (milpas) were destroyed to persuade the populations fleeing to the sierra to deliver their leaders and accept peace. ${ }^{\text {II }}$ Kino's narrative is rather reticent on the climate of intimidation and threats which preceded the peace talks: General Fuente, who was responsible for the military campaign, was praised in Favores celestes for acting "with great prudence, experience, and acute Christian sense." 12

Finally, the Pima groups came forward to "make peace"; they pledged to deliver the heads of the instigators. According to the military analysis, they were induced to "sue for peace" by the "war and the hunger suffered." 3 The treaties were unequal, and the negotiations were dominated and the terms imposed by the victorious Spaniards, as stated by the war diary of General Fuente. It reports the contents of three peace agreements while the literature dedicated to Kino only mentions the treaty concluded in the presence of the Jesuit on August 30, 1695 , to which a decisive role was attributed. ${ }^{14}$ In fact, before that date, two more treaties had been signed: the first on August 15 and the second on August 25. ${ }^{15}$

The structure of the "general peace agreements," as Kino called them, was the same and corresponded to a consolidated legal-diplomatic

I I. Ibid., 583-84 and 656; H. E. Bolton, Rim of Christendom, 301-02.

I2. E. F. Kino, Cronica de la Pimería Alta, 32.

13. "... la guerra y anbre [sic] que padecian, les motivó a pedir la pas" ("war and hunger attacked them, moving them to sue for peace”: letter of Fuente to Diego de Almonacir, September 8, I695, in Charles W. Polzer and Ernest J. Burrus, eds., Kino's Biography of Francisco Javier Saeta, S.J. (St. Louis: Jesuit Historical Institute, I971), I64-65. Similarly, Manje's report in Ernest H. Burrus, ed., Kino and Manje, Explorers of Sonora and Arizona: Their Vision of the Future (St. Louis: Jesuit Historical Institute, I971), 328-29.

I4. Following Kino's narrative, reference is only made to the treaty of August 30 by H. E. Bolton, Rim of Christendom, 314-16, on which subsequent reconstructions have been based: see, for example, Charles W. Polzer, “An Epilogue to Kino's Biography of Saeta,” in Polzer and Burrus, eds., Kino's Biography, 257-330; and Domenico Calarco, Eusebio Francesco Chini. Epistolario (Bologna: Editrice Missionaria Italiana, I998), 378 and note I4.

I5. Fuente, Autos de guerra, treaties of peace: (August 2, I695), 636; (August 15, I695), Ibid., 691-95; (August 30, I695), Ibid., 699-700. See also the letters sent by Fuente to Kino, August I5, and to Diego de Almonacir, September 8, I695: "en diferentes parajes, se icieron los ajustes de la paz; y el último fue el día de Santa Rosa (August 30)." "In several places they ["the Indians"] made treaties of peace. The last treaty was made on the feast of Santa Rosa [August 30].) (Polzer and Burrus, eds., Kino's Biography, I 44, I64-66). On the conclusion of the first of the agreements Fuente informed Kino on August I 5 (ibid., I 44). 
schema that was substantially respected on this occasion. ${ }^{16}$ With the use of one or more interpreters, the soldiers questioned the tribal leaders as to who was responsible for what had happened before imposing the conditions: delivery of the perpetrators dead or alive ("muertos o vivos") and the return of the looted holy vessels, the return of the participants to their settlements to lead "a peaceful life," the transfer to the missions of tribes that had not already done so, the maximum respect for the missionaries under threat of reprisals, and military alliance with Spain. In a few words, General Fuente efficaciously summarized the conditions imposed on the Pima Sobaipuri: "propagation of the Gospel, with greater dedication to divine worship and respect for missionary fathers and fear of the Spaniards." ${ }^{17}$ In exchange, the victors would pardon the rebels, restoring their status as free vassals of the Crown, and the Spaniards would provide military support against enemies. ${ }^{18}$ This confirms that the pacification was coordinated and governed by the military. ${ }^{\text {I9 }}$

The Pima delegates, who arrived without weapons and with the command batons previously issued to them by the Spaniards, were willing to take responsibility for the revolts. A lucid pragmatism dictated the declarations of the indigenous leaders: "We have never gone to war against the Spaniards and Christian Indios, nor have we stolen cattle and horses. Why should we do so now that we have experienced the power of the Spanish weapons?"20 The peace agreements were stipulated orally. Spanish jurisprudence recognized their full validity, ${ }^{2 \text { I }}$

16. A. Levaggi, Diplomacia Hispano-Indígena; Beatriz Vitar, "Las relaciones entre los indígenas y el mundo colonial en un espacio conflictivo: la frontera tucumano-chaqueña en el siglo XVIII," Revista Espanola de Antropología Americana, 2 I (1991), 262-65.

17. Fuente explained, "podemo tener entendido que Dios permitió que se derramase la ynocente sangre [de Francesco Xavier de Saeta], en primicias de que después, con el castigo y redución, se avía de dilatar y propagar el santo evanjelio, con más veneración al culto divino y respeto a los Padres misioneros, y temor a los españoles." "We must try to understand that God has permitted this innocent blood to be shed [by Francesco Xavier de Saeta] as the first fruits of what, after the punishment and the return of the Indians, will be for the spread and propagation of the holy gospel. Now there will be more devotion at divine worship, respect for the missionary priests, and fear of the Spaniards.") See the letter sent by Fuente to Diego de Almonacir, September 8, in Polzer and Burrus, eds., Kino's Biography, i68. On the decisive role of the military in supporting the activity of the missionaries see: Bernd Hausberger, "La violencia en la conquista espiritual: las misiones jesuitas de Sonora," Jahrbuch für Geschichte von Staat, Wirtschaft und Gesellschaft Lateinamerikas, 30 (1993), 37-39.

18. Fuente, Autos de guerra, (treaty of peace, August I5), 694; Ibid., (treaty of peace, August 30), 700.

I9. As pointed out by Naylor and Polzer, eds., The Presidio and Militia, 8.

20. Fuente, Autos de guerra, (treaty of peace, August 15), 693-94.

21. A. Levaggi, Diplomacia Hispano-Indígena, 3 I. 
which was sanctioned by a ceremonial performance of actions and rituals with strong symbolic value: the admission of guilt and repentance by the losers, and their acceptance of the conditions imposed by the peace treaty, participation in the joint celebration of Mass, the embracing of peace - that also had a formal value in the Indigenous diplomatic code, ${ }^{22}$ the exchange of food and gifts, the release of Indian prisoners, and the return of horses requisitioned by soldiers. Both General Fuente's and Father Kino's reports remarked that the Indian delegates showed themselves "grateful, contented and repentant." 3 Father Kino commented thus on the agreements of 1695: "By grace of God, established on that occasion was one of the most solid and stable peace agreements that have endured." ${ }^{24}$ But the agreements strongly conditioned and changed the lifestyle of the indios amigos.

Could the Pimas really be trusted? Fuente was certain that they could: in his war diary he makes a personal assessment of the convenience to the native populations of respecting the treaties: ${ }^{25}$ they were agricultural societies settled on fertile land rich with water, a peasant people, not with a warrior culture like that of the indomitable Apaches. Time would show that the general was correct in his assessment.

\section{The Peace Agreements of i 695}

The peace agreements of 1695 should be recognized as a veritable turning point that should be considered more carefully than it has been. It is from March 1695 that one must start in order to understand the narrative proposed by Kino in the Favores celestiales and in the biography dedicated to Saeta, his coreligionist killed during the uprising. In short, the treaties imposed upon the Sobaipuri conditions that allowed the Jesuits to proceed in their activities and Kino to organize explorations northwards and safely enter unknown territories. Following the treaties, soldiers carried out periodic inspections, often in concomitance with the visits of Catholic priests to tribes of neophytes or ones undergoing conversion. Once again, the reports by Spanish officers can be substantially integrated with the accounts by priests. The former described inspections that were more attentive to

\footnotetext{
22. Beatriz Vitar, "Las relaciones entre los indígenas y el mundo colonial," 263.

23. Fuente, Autos de guerra, (entry for August I 5), 694; Polzer and Burrus, eds., Kino's Biography, I 50 , I90.

24. E. F. Kino, Cronica de la Pimeria Alta, 33; Fuente, Autos de guerra, 690.

25. Ibid., (treaty of peace, August 30), 700.
} 
the military dimension; the latter were almost exclusively concerned with descriptions of the progress of evangelization and pastoral aspects. But both were united in recording expeditions to pursue the joint project of temporal and spiritual conquest. Consider, for example, an account by Lieutenant Cristóbal Martín Bernal: during November 1697 , Bernal went north together with Kino and a garrison of twenty-two armed men, halting in the settlements of Pima Sobaipuri, which had entered the ranks of the indios amigos after the treaties of $1695 .{ }^{26}$ Thanks to Bernal's report, we can uncover aspects on which Kino did not dwell in his own account. The soldiers also halted at the mission station of Cocóspera, where the lieutenant arrived after having been discharged by the missionary. This was not the first inspection: the military noted that many obligations had not been fulfilled; they therefore repeated to the assembled population the duties to which they were bound by the stipulations of the treaties they had made with the victors and warned that those who flouted those obligations would be punished. Perhaps the most invasive imposition was stable residence in the pueblo, in adobe houses, in accordance with the Crown's plan to create inhabited centers in which to gather the population dispersed in the territory. And that "no one may go into the mountains," the shelter of rebels. The Spaniards would come back to check. ${ }^{27}$ The Sobaipuri were forbidden to have contacts of any kind with the warrior tribes, confirming the relationships between Sobaipuri and Apaches_relationships feared by the Spaniards all the more after the revolt of 1695 . The enemies of the Spaniards, primarily the Apaches, were now to be the enemies of the Sobaipuri. The Sobaipuri had made a choice of sides that definitively unhinged the old system of alliances that had united sedentary groups like the Pima, living off agriculture, with nomadic and warrior nations like the Apaches. Only after 1695 did the Pimas Sobaipuri become the armed wing of the Spanish and also Kino's auxiliary troops in his battle against the Devil and the Devil's allies, the

26. Bernal's military report has been published in Rafael Pérez-Taylor and Miguel Ángel Paz Frayre, eds., Materiales para la historia de Sonora (México: Universidad Nacional Autónoma de México, 2007), 87-Ior. On Kino's visits in the territories of the Sobaipuri, see also D. J. Seymour, "Delicate Diplomacy on a Restless Frontier: Seventeenth-Century Sobaípuri-O'odham Social and Economic Relations in Northwestern New Spain, Part I," New Mexico Historical Review 82:4 (2007): 469-99.

27. Pérez-Taylor and Paz Frayre, eds., Materiales para la historia de Sonora (November 30, I697, San Antonio de Cocóspora), roo. Bernal and Kino travelled together until November 26, I697. Ibid., 99. 
Apaches. Also the vocabulary of the Pima referred to the definitive split: "Apache" became the term used to denote the enemy. ${ }^{28}$

While for the military command application of the peace treaties meant patrolling the territory and preventing revolts, for the Jesuits the treaties were bound to favor Christianization. With clear awareness, Kino emphasized that conversion of the Pima must be considered a fundamental objective not only from the spiritual point of view but also in regard to effective defense of the border territories: "If this [Pima population] were favoured," Kino wrote in 1697, hoping that the authorities would grant the Pima-by now allies - the concessions usually provided for indios amigos, "it could yield much more in all fields and especially in combatting the enemies of this province of Sonora, the Jocomes and the Apaches." 29

\section{Instruments of the Devil}

Enimigos (enemies) and rebeldes (rebels) were problematic legal and military categories in the teleological interpretation that missionaries gave to events and to their own role. If the repentance of the former and their renewed alliance signified redemption, the irreducible hostility of the latter signified the Devil's presence: the war was legitimate and "necessary," as Kino would maintain, using the lexicon of law and theology.

Nomadic and semi-nomadic warrior groups, incompatible with the sedentary agrarian economic and social model introduced by the Spaniards and the missionaries, were able for decades to outmaneuver garrisons armed with arquebuses. These were the Jocomes, Janos, Yumas, Mansos, and tribes associated with the Apache nation, although the remarkable distinctions among these Indigenous peoples is at odds with the univocal label "Apache" used by the Spaniards, who were still unable to draw the distinctions necessary in the context of a plurality of tribes and nations. ${ }^{30}$ These warrior groups

28. Karl Jacoby, Shadows at Dawn: An Apache Massacre and the Violence of History (New York, London: Penguin Books, 2009), 20.

29. E. F. Kino, Cronica de la Pimería Alta, 207.

30. Keith H. Basso, "Western Apache," in A. Ortiz (ed), Handbook of North American Indians, 462-88; Morris E. Opler, "The Apachean Culture Pattern and Its Origins," (ibid., 368-392); J. L. Mirafuentes Galván, "Seris, apaches y españoles en Sonora. Consideraciones sobre su confrontación militar en el siglo XVIII," Históricas 22 (1987): 18-29; Cecilia Sheridan Prieto, “'Rebelión o resistencia?: Tierra de guerra en el noreste novohispano," in Salvador Broseta, Carmen Corona, and Manuel Chus 
moved aggressively along the Spanish borders; they lived by plunder; their actions hindered evangelization; they resisted Christianization; they never submitted. In short, they were the enemies of the Spanish Crown and the enemies of the faith. The war against these tribes was more than justified within the parameters of European law; likewise, also, the doctrine of the Catholic Church legitimated the use of weapons for defensive purposes. ${ }^{3 \text { I }}$ The impossibility of pacification of the nomadic and warrior tribes of the frontier made all of them the "enemy" by definition. Generals stationed on the northern borders, like Fuente, urged a war of "sangre y fuego" (blood and fire) against the Apache tribes and their allies. ${ }^{32}$ The Apaches became the instrument of the Devil, "the common enemy" (el común enemigo): his means to prevent the missions' work and therefore the salvation of peoples. The mechanism of inclusion foreseen by the Jesuits' universal evangelization project halted with the Apaches, and hence the illusion that they could be converted. ${ }^{33}$ The spiritual and political path of forgiveness and grace was closed to the recalcitrant and recidivist tribes. At this point not only was war against the nomadic and pagan tribes just, it was also necessary. The human conflict mirrored an eschatological struggle between Good and Evil, between Christianity and idolatry, between God and the Devil. ${ }^{34}$ Just like demonic sowers

(eds), Las ciudades y la guerra, I750-1898 (Castellón de la Plana: Universitat Jaume, 2002), I9-46; Bernd Hausberger, Für Gott und König. Die Mission der Jesuiten im kolonialen Mexiko (Wien, München: Verlag für Geschichte und Politik, 2000), I8I-96; Christophe Giudicelli, “¿Naciones’ de enemigos? La identificación de los indios rebeldes en la Nueva Vizcaya (siglo XVII),” in Albert (ed), El gran Norte Mexicano, 27-66.

31. See above, note 8.

32. Charles W. Polzer, "Long before the Blue Dragoons: Spanish Military Operations in Northern Sonora and the Pimería Alta," in Bruno J. Rolak (ed), Military History of the Spanish-American Southwest (Fort Huachuca: U.S. Army, I976), 7.

33. "It already seems that the prophecy of Fra Giovanni di Gesù is being fulfilled, that the Apache are indeed embracing our holy faith, and forming a select Christendom" (The illusion is expressed in the letter by Antonio Leal, in response to information received from Kino, August 20, I699.) Kino, Cronica de la Pimería Alta, 6o.

34. See Salvador Bernabéu Albert, "El Diablo en California. Recepción y decadencia del Maligno en el discurso misional jesuita," in Salvador Bernabéu Albert (ed), El Septentrión Novohispano: Ecohistoria, sociedades e imágenes de frontera (Madrid: CSIC, 2000), I49-60; Salvador Bernabéu Albert, "La invención del Gran Norte ignaciano: la historiografía sobre la Compañía de Jesús entre dos centenarios (1992-2006)," in Bernabéu Albert ed., El Gran Norte Mexicano, I65-2 I I, particularly I7779; Fernando Cervantes, "El demonismo en la espiritualidad barroca novohispana," in Clara García Ayluardo and Manuel Ramos Medina (eds), Manifestaciones religiosas en el mundo colonial americano, vol. I (México: Condumex, I995), I25-40. 
of discord, those tribes "infested" 35 the lands conquered by the Spanish Crown and the Christian God. Kino watched with satisfaction the Spanish soldiers joining the Pima warriors-once rebellious but now repentant and loyal allies - as they danced around a pole on which they had impaled the scalps of their enemies. ${ }^{36}$ Prisoners of war still children were taken to missions to be baptized and thus, in Christian doctrine, saved from eternal perdition. ${ }^{37}$ The bells of the churches on the border rang out to celebrate the announcement that the enemy had been defeated. The missionaries hailed as "a fine victory," "fortunate events," "felicitous victories" $3^{8}$ the outcomes of mortal conflicts in which the women of the enemy were killed as they gathered booty on the battlefield. Also "good news" was the victory of the Sobaipuri and the death of 300 enemy Apaches in April I697. ${ }^{39}$ Kino emphasized the bond between the military success and divine benevolence, and he insisted on the salvific significance of the victory. The stake was extremely high: the salvation of souls. The blood of the enemy was the emblem of Christianity's victory and divine benevolence. The Pimas and their military skills were among the "effective means" and the "significant benefits" (in Kino's words) granted by the Christian God: they were instruments to defend and extend the boundaries of Catholicism in the war against the Devil and his collaborators, the Apaches.

35. Eusebio Francisco Kino, Breve relación de la insigne victoria que los pimas sobaipuris en 30 de marzo del año de 1698 han conseguido contra los enemigos de la provincia de Sonora, in Materiales para la historia de Sonora, 82-83, IоI-06. Furthermore, E. F. Kino, Cronica de la Pimería Alta, I5.

36. Kino wrote, "Hallamos a los hijos pimas de Quiburi muy joviales y muy amigables, y que estaban bailando las caballeras y los despojos de I5 enemigos jocomes y janos que pocos dias antes habian matado, cosa que nos fue de tanto consuelo que el señor capitán Cristóbal Martín Bernal ... y otros muchos entraron en la rueda y bailaron gustosos en compañia de los naturales." "We found the natives of Pima Quiburi to be very jovial and friendly. They were actually dancing with the scalps of ${ }_{5} 5$ enemy Jocomes and Janos whom they had killed some days before. The sight caused so much pleasure that the captain Cristofor Martín Bernal... the sergeant, and many others formed a circle to dance merrily along with the natives.”) Kino, Cronica de la Pimería Alta (entry for November 9, I697), 40. The episode is also described in the military reports of Manje (Burrus, ed., Kino and Manje, 336, 36r) and Bernal (Pérez-Taylor and Paz Frayre, eds., Materiales para la historia, 91.

37. Kino, Cronica de la Pimería Alta, for example pages $43^{-44}$.

38. Ibid., for example pages $43-44,82-84$. See also F. Jackson Smith, The relación diaria of Father Kino, 6-7: "The first of the two supplementary short reports gives rare insight into an element of Kino's character that has been understated by his biographers. He clearly condoned the slaughter of Indians whose depredations marked them as enemies of Cross and Crown."

39. See Burrus, ed., Kino and Manje, 578-84; Kino, Cronica de la Pimería Alta, 51, 71, 87; Kino, Breve relación de la insigne victoria, I00-01, I05. Tendentially hagiographic is the reconstruction by Bolton, Rim of Christendom, 379-84. 
Also pertaining to the legal and ideological context of the 'just war' was Kino's praise of Jironza Petris de Cruzat, a member of the military high command and responsible for territorial control of the province of Sonora, including armed expeditions. Among his merits, Kino recalled, was "having defeated the Jocome and Jano enemies." ${ }^{\circ}$ Together with encomia "for having contributed to bringing peace and harmony to all regions within these borders," Kino added an exhortation to act against the enemies with prayer but also with the sword in order to ensure "lasting peace," ${ }^{41}$ as the prime objective of a just war. There is no doubt about the military value of the suggestion: cited in the same missive is "the letter of Captain Luís Pranillo, in which he states that even the Suma, having seen half of their people killed in the last attack launched by the Pima against them, were forced to seek peace and to retreat to the lower part of the Río del Norte."

It should also be said that the conviction of the legitimacy of the war against the aggression by nomadic tribes was accompanied by a concern, which was also that of the Spanish Crown, to avoid the improper use of violence and weapons. ${ }^{42}$ But the reality outweighed the good intentions: the difficulties of the Spanish garrisons induced Kino to perform a military coordination role entirely at odds with his jurisdictional and disciplinary capacity. ${ }^{43}$ Kino breached the legal limit of the "just" war by organizing preventive attacks: in fact, he urged the native allies to wage war against the Apaches; "Even though I was very busy with the construction of two churches," he wrote, "I advised Captain Coro and the Pima and Sobaipuri population of the north to mount a [military] expedition to the lands traversed by the enemy Apaches." ${ }^{44}$ And again: "I had to advise the Pima to be ready to

40. Kino, Cronica de la Pimería Alta, i8.

4I. See the letter to Jironza Petris de Cruzat, December 8, I698 (Domenico Calarco, Eusebio Francesco Chini), 302.

42. For example, see D. Calarco, Eusebio Francesco Chini, 302.

43. "Por cuanto los presidios no remediaban como se deseaba en las muchas invasiones y hostilidades, robos y muertes... que tan a menudo y todos los años hacian los enemigos apaches, tratamos por ahora al poniente hacer una entrada con los pimas a las tierras por donde suelen andar y venir dichos enemigos apaches." ("Because the garrisons were incapable of defense against the incursions, hostilities, robberies and murders... so frequently perpetrated by the enemy Apaches, we in the West agreed with the Pima to launch an expedition to the lands traversed by the enemy Apaches." Kino, Cronica de la Pimería Alta, I I5). The difficulties of the Spanish garrisons are confirmed by Manje. (Burrus, ed., Kino and Manje, I3I-32).

44. See, for example, the letter of Lieutenant Juan de Casos (January 28, I703): "Dios nos conceda que podamos lograr y coger a estos malévolos apaches y les demos un porrazo Bueno, y para ello solicitaré convocar 
go with the soldiers on an expedition against the enemies of the province, the Jocomes, the Janos, the Sumas and the Apaches." ${ }^{45}$ And it was to Kino that Lieutenant Tuñon y Quirós wrote reminding Kino that he should respect "the promise made by you and your natives to help us castigate these enemies." ${ }^{46}$ Likewise, the Jesuit Augustín de Campos wrote to Kino from his mission at San Ignacio asking him to "treat with the Sobaipuri natives so that they conduct a campaign which brings some peace in this time." 47

What was the reaction of Kino's superiors in Mexico City? Not positive: his superior, Francisco Xavier Mora, solicited the removal of Kino, whom he accused of exploiting the Pima for illegitimate purposes. ${ }^{4}$ According to Mora, Kino pushed the Pima into constant expeditions with the objective "of making the Pima the capital enemies of the Jocomes, Janos, Apaches and other nations that invade this province," with the advantage that "the enemies, being distracted by the wars against the Pima, would not cause damage in this area." Mora accused Kino of neglecting his pastoral duties, and primarily the Christian education of converts, to pursue secondary and dangerous objectives. According to the usual interpretation, the report written by Mora to denounce Kino's conduct was prompted by jealousy and envy. But this is a hagiographic explanation which ignores Kino's own statements. ${ }^{49}$ In fact, Mora's denunciation shows that the Mexican Society of Jesus was riven by disputes over the aims and

alguna gente del poniente, y así V.R. solicite la del norte para que todos juntos algo bueno." "God allows us to take these evil Apaches and teach them a good lesson: to do so, I will ask to ensure the coming of people from the west and your Reverence to do so for those of the north so that united together they can achieve a good result.") Kino, Cronica de la Pimería Alta, i 6.

45. Ibid., 39: "En I7 de marzo de I697 entré otra vez a San Pablo de Quiburi .. . avisándoles juntamente a que estuviesen prevenidos a ir con los señores soldados a la entrada contra los enemigos de la provincia jocomes, janos, sumas y apaches.” Similarly, 88.

46. "...y así ha llegado el caso de aceptar la palabra que V.R [Kino] y sus huijos me dan que me ayudarán para el castigo de dichos enemigos": Ibid., (February 25, 1704), I40-4I. Similar requests were made by Captain Manje (Burrus, ed., Kino and Manje, I9o.)

47. Kino, Cronica de la Pimería Alta, I I 5-I6: "V.R. trate con los hijos sobaipuris (son los pimas del norte) hagan una campaña en aplacando un poco el tiempo." (January 28, I703).

48. See Mora's report, which consists of 72 indictments, published in Kino ifrustrado alguacil y mal misionero? Informe de Francisco Xavier de Mora SJ al Provincial Juan de Palacios, Arizpe, 28 de mayo de ı698, ed. Gabriel Gómez Padilla, and Enriqueta Valenzuela Tourniayre (Guadalajara, México: Universidad de Guadalajara, 2004), 28-73.

49. Not persuasive is the traditional interpretation, first put forward by Bolton, Rim of Christendom, 334-42 and 385-90, that Mora was induced to write the report against Kino's conduct by jealousy and envy. Similarly D. Calarco, Eusebio Francesco Chini, 4I7. 
limits of missionary action. What was the task of missionaries? "Was it for these purposes that we came to the missions?" ${ }^{\circ}$ asked Mora in regard to Kino's behavior. How did matters turn out? Kino was not transferred, because he was given a key role in the objective of

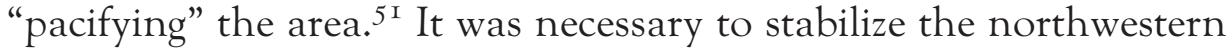
borders. But not even the Spanish Crown supported Kino's dream of conquering the northern lands with the Catholic Christian faith, which would, by necessity, entail Spanish military support.

\section{The Warrior Priest}

The military coordination that Kino performed with conviction, urging the Pima to wage war against the Apaches, can be understood if it is set in the conceptual, legal, and doctrinal framework of the "just war" and the legitimacy of the use of force as long as it is defensive in its purpose. Of course, the legal dimension of the problem is indivisible from the moral and religious ones. The dichotomous and theological interpretation of reality, the demonization of the enemy, and the placement of the Apaches (and their allies) in the frame of an eschatological battle between Good and Evil made the war not only just but also necessary. More generally, Kino's mediation of the war highlights the firmness, not to say the obsession, ${ }^{52}$ with which he pursued the ambition of spiritually conquering the entire continent-from Pimería Alta to California, from Arizona to Canada - thereby entirely fulfilling the Jesuit and Papal mandate to convert peoples. Cultivating visionary, religious, as well as geo-political principles, Father Kino advanced relentlessly northwards, with the goal of gaining peoples and lands for the two majesties, God and the Catholic sovereign of Spain. Indispensable for this program of planetary spiritual conquest was the military collaboration of the indios amigos in the attempt, which ultimately proved fruitless, to overcome the resistance of the non-submissive

50. Kino ifrustrado alguacil y mal misionero?, 55, § 45: "Uno de los principales motivos de estas caminatas [journeys] ha sido para que el Padre Kino se halla hecho convocador, ô Cooperador para que los Pimas se hagan enemigos capitales de los Jocomes, Xanos, Apaches, y de mas Naciones, que invaden esta Provincia... A este fin venimos nosotros a las Missiones?" See also 55, § 46: "otros [Padres] discurren, que es cosa muy contraria a nuestro ministerio ["mandar a los Pimas, que vaian solos a pelear"]. "Other Fathers say it is wholly contrary to our ministry to command the Pima to combat on their own.") Similarly, $52, \S 35$.

51. See the letter of the Superior General Tirso González (Rome, December 27, I698), in Polzer and Burrus, eds., Kino's biography, 28-30.

52. See Hausberger, El padre Eusebio Francisco Kino, 223-25. 
tribes and their violent incursions - the Devil's instruments to prevent missionary action and inception of the Christian order. More than an "agent of the Spanish Crown," 53 Kino was an agent of God. The Pima were the arms-bearers of the Spaniards but first and foremost of Kino and his battle to defeat the pagan idolatry allied with the Demon. Against the enemy of humanity and its instruments, the only possible solution was all-out war, not peace. 